Bryant University

Bryant Digital Repository

History and Social Sciences Faculty Journal Articles

Spring 3-1-2016

\title{
What Does it Mean to Teach Interpretively?
}

Jennifer Dodge

Richard Holtzman

Bryant University

Merlijn van Hulst

Dvora Yanow

Follow this and additional works at: https://digitalcommons.bryant.edu/histss_jou

Part of the Education Commons, and the Social and Behavioral Sciences Commons

\section{Recommended Citation}

Dodge, Jennifer; Holtzman, Richard; van Hulst, Merlijn; and Yanow, Dvora, "What Does it Mean to Teach Interpretively?" (2016). History and Social Sciences Faculty Journal Articles. Paper 88. https://digitalcommons.bryant.edu/histss_jou/88

This Article is brought to you for free and open access by the History and Social Sciences Faculty Publications and Research at Bryant Digital Repository. It has been accepted for inclusion in History and Social Sciences Faculty Journal Articles by an authorized administrator of Bryant Digital Repository. For more information, please contact dcommons@bryant.edu. 


\title{
What Does It Mean to Teach 'Interpretively’?
}

\author{
Abstract: \\ In recent decades, the 'interpretive turn' has gained traction in the empirical social sciences. \\ While the contributions of interpretive research and interpretive research methods are clear, we \\ wonder: Does an interpretive perspective lend itself to—or even demand-a particular style of \\ teaching? This question was at the heart of a roundtable discussion organized at the 2014 \\ International Conference of Interpretive Policy Analysis at Wageningen University in the \\ Netherlands. This essay reports on the contours of our discussion, with a focus on our reflections \\ upon what it might mean to teach 'interpretively'. Prior to outlining these, we introduce the \\ defining characteristics of an interpretive perspective and describe our respective experiences \\ and interests in this conversation. We close this essay, in the hope that it might constitute the \\ beginning of a wider conversation, with an invitation to other interpretive-minded teachers.
}

\section{Key Words:}

context, interpretive thinking, iteration, local knowledge, meaning making, participatory processes, reflexivity, teaching practices 
In recent decades, the 'interpretive turn’ has gained traction in the empirical social sciences. Approaches adopting this perspective share 'an overarching appreciation for the centrality of meaning in human life in all its aspects and a reflexivity on scientific practices related to meaning making and knowledge claims' (Yanow and Schwartz-Shea 2014, xiv). While the contributions of interpretive research and interpretive research methods are clear, we wonder: Does an interpretive perspective lend itself to—or even demand—a particular style of teaching?

This question was at the heart of a roundtable discussion we organized at the summer 2014 International Conference on Interpretive Policy Analysis at Wageningen University in the Netherlands. The starting point of this roundtable was our shared belief that it does, indeed, make sense to think about teaching 'interpretively.' But what does that mean? How does it differ from other ways of teaching? What 'lessons learned' can we glean from our varied experiences as interpretive researchers which might be productively applied to interpretive teaching? What are the primary objectives of this approach to teaching, and do these objectives differ from those of more 'traditional' approaches? Does an interpretive approach change the respective roles of teachers and students, their self-understandings, or their relationships? Might this approach be applicable for some sorts of students, courses, and subjects, but not for others? And what is 'good' teaching in an interpretive modus?

This essay reports on the contours of our discussion, with a focus on the reflections each of us made based on our several experiences teaching. Prior to outlining these, we briefly introduce the defining characteristics of an interpretive perspective. We close this essay, in the hope that it might constitute the beginning of a wider conversation, with an invitation to other interpretive-minded teachers. 


\section{Thinking Interpretively}

As a starting point, we can think about teaching interpretively as the application of interpretive methods and methodologies to teaching. Interpretive methodologies and their attendant methods draw on ideas that derive from phenomenology and hermeneutics, some critical theory, with echoes in pragmatism, symbolic interactionism, and ethnomethodology (Yanow 2014). From phenomenology come three key ideas: the place of a priori knowledge, intersubjective knowing, and situated or contextual knowledge. Phenomenologists focus on making meaning of events, acts or situations, 'bracketing' the phenomenon itself and looking, instead, at sense-making (consider, for example, the work of Edmund Husserl and Alfred Schütz; see Berger and Luckmann 1966). By contrast with positivist philosophies, phenomenologists argued that the world cannot be apperceived directly through sense data. Instead, something intervenes between senses and sense-making-a lens, a frame, a paradigm, a weltanschauung or worldview—which shapes the meaning we attribute to what we observe. This ‘filter' develops out of our prior knowledge, education, and experience. Meaning-making is not infinite, however, because we live in interaction with one another within societal contexts, and in and through those interactions we develop an intersubjectively shared understanding of the world around us — the common sense, everyday, unspoken/unwritten, in part tacitly known 'rules of engagement' that enable us to navigate our lives.

Hermeneutics contributes the idea of interpretive or epistemic communities of knowers: a group whose members share a set of rules for interpreting the objects of their study, and the set of rules themselves (think Wilhelm Dilthey, Hans Georg Gadamer, Paul Ricoeur, Charles Taylor; see, for example, Taylor 1979/1971). As we create the artifacts (language, objects, and 
acts) that populate our lives, we embed within them what is meaningful to us (values, beliefs, feelings), in a representational or symbolic relationship. Each time we use one of these artifacts, we reinstantiate its meanings - although here is where change is also possible. Symbolic meanings are shared within interpretive communities, but not necessarily across different such communities. As they accommodate multiple meanings, symbolic artifacts need to be investigated for what is meaningful in any given situation. The hermeneutic circle captures the interrelationship between parts and wholes, the one having meaning only in relation to the other. It also reflects learning processes: one learns from what one knows to what one does not yet know. The interpretive process 'moves forward in time in a continual process toward deeper and richer understanding’ (Bentz and Shapiro 1998: 170).

From pragmatism, interpretive thinking draws the idea of inquiry being sparked by a puzzle or surprise. The inquiry is context-specific (this puzzle), and, like the hermeneutic circle-spiral, inquiry is iterative and recursive. Critical theory adds the dimensions of powersensitive inquiry and an attention to silent, and silenced, discourses. Symbolic interaction and ethnomethodology offer other versions of these several ideas.

These ideas can, and do, inform not only research practices, but teaching practices as well.

\section{Our Respective Experiences and Interests}

While each of us came to the question of teaching interpretively with different teaching experiences (e.g., more and less seniority; European and US contexts; graduate and undergraduate students; working in public administration, public policy, political science, and organizational studies departments; etc.), we shared a strong interest in launching a conversation 
that might speak to, and with, a wide and diverse range of teachers. Here, each of us takes up the particular set of interests he or she brought to the table.

Author 1. As I write this, I am an assistant professor in my fourth year of teaching in a master's program of public administration. My research focuses on the ways interpretive practices (framing, discourse, narrative) influence policymaking processes. I'm also interested in the ways civic organizations organize citizens (broadly speaking) to influence public policy. I teach about these topics. When Author 2 invited us to think about what teaching interpretively means for us, I began by contemplating the ways I bring my skills and practices as an interpretive researcher into the classroom and how I might be more intentional about using them to create 'practices of freedom.' I had picked up a book by bell hooks called Teaching to Transgress: Education as the Practice of Freedom. I wanted to understand more about what she meant by this intriguing title and whether teaching interpretively could be a part of teaching as a practice of freedom. I've had a sense that I wanted to shift my teaching in a way that would be more dynamic, engaged, and liberating, while still trying to understand what this would mean in practice. I wanted to draw on my practices as an interpretive researcher, and on what I could learn from bell hooks' book, to see if I could better understand what types of interpretive teaching practices might be liberating for students and myself, what types might be less so, and how to continually open up space for problem solving in the classroom that can handle complexity and contradiction.

Author 2. My engagement with the idea of teaching interpretively was stimulated by a shift in perspective. Rather than asking, 'What do my American Politics students need to know?' I have begun to ask: 'What do my students need to be able to do?' Unlike the straightforward delivery 
of course content, the development of skills and aptitudes (e.g., innovative and adaptable thinking, organizational design, information literacy, data analysis, and communication) cannot be served up by instructors and consumed by students. These must be practiced. But how can practices be taught? Perhaps the answer lies in an instructional approach derived from and grounded in the concepts and processes of interpretive thinking. To explore this idea, I sought to adapt five components of an interpretive approach by reconceiving teaching as a form of practice that is (1) problem- or puzzle-driven, rather than theory- or methods-driven; (2) developed from the student's own prior knowledge; (3) practical in its orientation and presentation; (4) driven by an open-ended, iterative learning process built around doubt, discovery, failure, reflection, and repetition; and (5) aimed toward contextual meaning-making, rather than generalization. To assess the application of this approach to undergraduate teaching and learning, during the fall 2013 semester I prototyped a new curriculum in my senior undergraduate seminar for Politics \& Law majors. My hope is that such experiments might contribute to, and perhaps widen, the conversation about skills-based teaching and learning.

Author 3. I have been teaching for a little over ten years, mostly first-year undergraduates in Public Administration and mostly courses in qualitative methods and organizational theory. While working on my PhD I did quite a bit of teaching, after receiving little training. I developed, as I think many practitioners do, my own ways of going about it: trying out things, talking to colleagues and students, and occasionally reading texts, in order to become a better practitioner. Some years ago, I started to think through the way I teach, being unsatisfied with what I was doing and gaining more interest in what motivates students to show up to class, to read the assigned material beforehand, etc. The roundtable helped me to also engage the 
relationship between doing research and teaching. Preparing for it I asked myself, 'What elements of interpretivism call for a certain kind of teaching?' and 'What teaching principles might those elements suggest?' A tentative answer to the first question would be 1) an interest in meaning making practices coupled with a sensitivity to local knowledge and contexts, 2) an iterative, cyclical, abductive way of working towards results, and 3) an interest in the sociopolitical construction of knowledge, joined with a modesty towards our own products and a critical stance towards the powers that be.

Author 4. I have thought on and off over nearly 40 years about some of the ways in which teaching may be informed by an interpretive orientation. Not all practitioners reflect on what they do, let alone reflecting in the midst of doing it (itself perhaps an interpretive orientation); and so it is, indeed, possible for people to conduct their research in ways consistent with interpretive philosophical-methodological principles, but whose teaching practices are informed by other presuppositions. Still, I believe there is something distinctive about an 'interpretive' mode of teaching. For me, this is the antithesis of the authoritarian, 'my way or the highway' mode of teaching that characterized significant arenas of my own childhood experiences. That means, for me, first and foremost, treating students as equals-in-humanity (enacting Buber’s 'IThou' relationship). In practice, this means trying to access and understand students' 'local knowledge'; being open to multiple possible interpretations of what we are discussing; decentering my expertise and authority in the classroom, therefore, in order to make room for their own expertise in their lives and ways of thinking; and being open myself to learning. Some of this I learned from theorist-practitioners whose thinking I encountered while working toward my Master’s degree: Paolo Freire (e.g., 1970), who advocated for decentering authority and 
expertise by starting with what his students knew (a hermeneutic principle); Carl Rogers (1980), whose client-centered psychotherapy focused on figuring out what was on his patients' minds, rather than imposing his own meaning on what they told him; and William Perry (1970), whose research revealed the hidden curriculum of undergraduate education which worked to move first-year students from their absolute beliefs in a world of blacks and whites to more variegated beliefs in a world of mottled greys, an idea I re-encountered later in feminist standpoint theories (e.g., Harding 1987). Taken together, these works suggest that 'interpretive’ instructors might design curricula in ways intended to support developmental shifts, including assigning work that asks students to draw on their own experiences and which challenges assumptions about objective and universal knowledge claims.

\section{Reflections on What it Means to Teach Interpretively}

Are we teaching interpretively like we research interpretively? This might mean honing listening skills, engaging in explicit co-creation of 'reality', and searching for understanding. It may also mean appreciating local knowledge(s) and perspectives and iteratively processing analysis and engaging in knowledge creation, all of which are orientations used in interpretive research. Looking across our individual reflections (in the previous section) and building on the discussions we had at the roundtable with a wider group of colleagues, we suggest three general themes regarding the practice of teaching interpretively.

\section{Teaching interpretively involves thinking interpretively, and is therefore akin to teaching} interpretive processes 
An interest in local knowledge, context, and meaning is a cornerstone of interpretive research. Interpretive teaching would, then, mean stimulating student interest in these three orientations. Teaching interpretively, we posit, would also involve valuing students’ own knowledge(s), backgrounds and prior experiences. What students might bring to a classroom is not just formal knowledge picked up in educational environments, but also other kinds of knowledge derived from experiential and other forms of knowing, all of which can be valuable in classroom interactions, serving as potentially interesting material to work with. Teaching interpretively might also translate into a teaching programme that would allow students to abductively explore their worlds, like interpretive researchers. This would mean creating the time, space and opportunities to try things out and to experience how learning about things involves actively engaging them. Students should be provided with guidance and a safe space to discover, fail, reflect, and repeat their way through individually-selected research projects. Finally, teaching itself could become a constant searching for new ways of working, with the risk (or advantage) of putting both the teacher and the students on unstable ground.

\section{Teaching interpretively involves opening critical participatory processes in the classroom}

bell hooks says, 'Theory is not inherently healing, liberatory, or revolutionary,' but it can be 'when we ask that it [fulfill this function] and direct our theorizing towards this end' (1994: 61). hooks identifies a link here between the act of theorizing and the experience of liberation. The implication is that efforts to engage students in theorizing - that is, in applying different interpretive structures to real world policy problems like poverty and healthcare (in the sorts of courses we are involved in) - would help them develop tools to question and think critically about the policy areas they are studying, including challenging problematic assumptions in the 
theories that guide public policies. Engaging students in theorizing would also involve challenging them to rethink their own theories and knowledge. Teaching interpretively also directs attention toward the means by which students participate, not just in the instructional process, but in determining what that instructional process will be. Aletta Norval, for instance, considers how participation may foster 'democratic subjectivity and the creation of open, critical participatory processes that can sustain practices of freedom’ (2014: 63-4). In these ways, teaching interpretively has to do with creating contexts that will spark students to think critically about their own theories, the theories that we teachers offer them in class, and the theories of the practitioners whom they study, try to understand, and in some cases emulate—or explicitly avoid emulating.

\section{Teaching interpretively means remembering that each student is an individual--and not just a}

\section{student, but a whole person}

The third theme of teaching interpretively concerns being sensitive to students' mixed backgrounds, prior experiences and abilities. Here is another analogy between teaching interpretively and researching interpretively. As one does interpretive interviews, one tries to understand where the interviewee is coming from and why s/he is telling us about her/his life in this particular way. This is akin to an ethnographic sensibility (Pader 2014). Such a way of engaging people applies to the classroom as well. Once again, we are interested in students’ prior experiences and background: What cognitive and experiential frameworks are they coming from? How do these compare with my own framework and to the framework presented in the material we are reading? This time, though, the engagement is not so much with their knowledge 
as interesting 'material to work with' as it is toward students as persons in whose development one potentially plays a role.

There are challenges here. How do we value the perspectives of students whose values we do not share (e.g., undervaluing women or making harmful assumptions about the poor)? The interpretive process becomes complex here. It is possible to share argumentation and evidence that challenge harmful assumptions, but this has to be paired with respect. Passionate humility, for instance, would suggest marrying one's own value commitments with the recognition that others may not share them (Yanow 2009)—an attitude one may strive to teach and model in teaching. Teaching interpretively would also call for reflecting on the ways in which authority is manifested in the classroom, in order to support a context for individual development and learning.

\section{An Invitation}

We came to this roundtable discussion with more questions than answers, along with a willingness to reflect on our own challenges in the classroom, an eagerness to hear about the insights and experiences of others, and an openness toward considering and experimenting with new ideas. We understood the occasion as a unique sort of 'professional practice panel,' organized with the hope that through collaborative reflection and discussion, all participants might come away with ideas for developing a healthier and more mutually-advantageous marriage between our too often estranged teacher and researcher selves. In this short essay we have just scratched the surface of the topic. We might ask, for instance, what elements of the regular set-up of courses and classrooms either prevent or stimulate interpretively-informed teaching. We have not drawn fully on the role of experiential learning or on theories of 
andragogy, both of which concern adult learners. We believe that giving students a structure in which to excel at learning is essential, but we have more work to do to formulate how this can best be achieved. The pragmatic considerations of this issue cannot be overlooked: In what ways is our ideal something that can be realized in the settings in which we teach? We would also be interested to learn about initiatives other interpretive-minded teachers have developed in their classes. There is much for interpretive teachers to explore.

\section{References}

Bentz, V. M. and Shapiro, J. J. (1988) Mindful Inquiry in Social Research. Thousand Oaks, CA: Sage.

Berger, P. L. and Luckmann, T. (1966) The Social Construction of Reality. New York, NY: Anchor.

Freire, P. (1970) Pedagogy of the Oppressed. New York NY: Herder and Herder.

Harding, S. (1987) ‘Introduction: Is There a Feminist Method?’ in S. Harding (ed) Feminism and Methodology, Bloomington, IN: University of Indiana Press, 1-14.

hooks, b. (1994) Teaching to Transgress: Education as the Practice of Freedom. New York, NY: Routledge. 
Norval, A. (2014) 'Beyond Deliberation: Agonistic and Aversive Grammars of Democracy: The Question of Criteria,' in A. Norval, S. Griggs and H. Wagenaar (eds) Practices of Freedom: Decentred Governance, Conflict, and Democratic Participation. Cambridge, UK: Cambridge University Press, 60-84.

Pader, E. (2014) 'Seeing with an Ethnographic Sensibility: Explorations beneath the Surface of Public Policies', in D. Yanow and P. Schwartz-Shea (eds) Interpretation and Method: Empirical Research Methods and the Interpretive Turn, $2^{\text {nd }}$ ed. Armonk, NY: ME Sharpe, 194-208.

Perry, W. G., Jr. (1970) Forms of Intellectual and Ethical Development in the College Years. New York: Holt, Rinehart, and Winston.

Rogers, C. R. (1980) A Way of Being. Boston: Houghton Mifflin.

Taylor, C. [1971] (1979)‘Interpretation and the Sciences of Man’, in P. Rabinow and W. M. Sullivan (eds) Interpretive Social Science: A Reader, Berkeley: University of California Press, 25-71.

Yanow, D. (2009) 'Ways of Knowing: Passionate Humility and Reflective Practice in Research and Management', American Review of Public Administration 39/6, 579-601. 
Yanow, D. [2006] (2014) 'Thinking Interpretively’, in D. Yanow and P. Schwartz-Shea (eds) Interpretation and Method: Empirical Research Methods and the Interpretive Turn, $2^{\text {nd }}$ ed. Armonk, NY: M.E. Sharpe, 5-26.

Yanow, D. and Schwartz-Shea, P. (eds) [2006] (2014) Interpretative and Method: Empirical Research Methods and the Interpretive Turn, Armonk, NY: M.E. Sharpe. 